DOI: https://doi.org/10.47405/mjssh.v6i8.946

\begin{tabular}{|c|c|}
\hline 4.581 & Malaysian Journal of Social Sciences and Humanities (MJSSH) \\
\hline $\begin{array}{l}\text { Malaysian Journal of } \\
\text { Social cciences and }\end{array}$ & Volume 6, Issue 8, August 2021 \\
\hline (MJ-SSH) & e-ISSN : 2504-8562 \\
\hline & $\begin{array}{l}\text { Journal home page: } \\
\text { www.msocialsciences.com }\end{array}$ \\
\hline
\end{tabular}

\title{
Identify The Big Five Personality Traits to Escalate Business Motivation In Food Technology Industry
}

Firman Kusumah Wardhana1, Aria Bayu Pangestu' ${ }^{1}$

${ }^{1}$ School of Business and Management, Institut Teknologi Bandung, Indonesia

Correspondence: Firman Kusumah Wardhana (firman kusumah@sbm-itb.ac.id)

\begin{abstract}
The overall purpose of this research refers to the real case in Chixar's business which points out that the instability of motivation in doing business is an aspect that has also become a concern for internal business members, given the business conditions that had experienced pivoting before and the necessity to pursue sales targets that are quite high in the business. new to pivoting, internal business has a strong desire to improve business performance but it is necessary to support it with analysis of personality traits and motivation factors for Chixar business members as the main basis. Regarding small business aspects, the implementation of human resources management is not implemented properly considering that small businesses have fewer employees so they are not a main concern to be considered in internal business, but small businesses are often focused on the orientation of sales and business operations. Therefore, the author focuses on the scope of research in the application of human resources management in small business which includes aspects of personality traits and motivating factors for doing business. Personality traits are aspects that are owned by each individual and affect individual behavior based on personal desires towards an achievement or expected goals, personality is an absolute and stable aspect and variable possessed by individuals who are associated with working behavior, motivation and goal-orientation. The author uses the Big Five Personality Traits framework to identify and analyze the types of personality traits and factors that underlie Chixar business members. Self Determination theory as the framework basis of the motivation factor is divided into two, namely intrinsic motivation and extrinsic motivation, both motivation factors are analyzed in depth on several sub-variables. Overall, the data analysis process was carried out using qualitative data methods with data collection processing stages which included individual assessment, in-depth interviews and focus group discussions. The results of data analysis show that there are differences in personality traits owned by Chixar business members and differences in extrinsic motivation factors despite the similarities that form intrinsic motivation. The results of the strongest and most implementable personality traits are Openness personality traits, the strongest intrinsic motivation factor is Relatedness factor and the strongest extrinsic motivation factor is Integrated Regulation. Regarding the findings, the author tries to recommend solution that it is necessary to implement a performance management system as the main implementation base for small businesses which includes establishing development objectives, communicating effectively, motivating employees, document performance, feedback, diagnosing performance problems and developing employees.
\end{abstract}

Keywords: big five personality traits, self-determination theory, intrinsic motivation, extrinsic motivation 


\section{Introduction}

Chixar is a business engaged in the probiotic poultry industry. Chixar's superior product itself is more focused on probiotic chickens, the content of this probiotic chicken is different from broiler chickens in general. The difference between the probiotic chicken from Chixar is different in terms of the chicken feed given, the probiotic chicken from Chixar is not injected with additional hormones, contains much less fat, more savory and odorless chicken meat.

In this research, author intended to focused on analyzing the personality traits and supporting factors that are able to influence business motivation and engagement. The useful findings from this research will be optimized due to assessing the importance factors of understanding personality traits and motivation factors especially in small business practices. Perhaps this research brings enhancement to Chixar's business performance.

\section{Literature Review}

\section{Entrepreneurship Motivation on Startup}

The development and execution of new opportunities in a dynamic and unpredictable world is referred to as entrepreneurship, entrepreneurship curriculum can promote the creation of a knowledge base in business administration as well as entrepreneurship competencies in personality characteristics and abilities, resulting in added benefit for students and the development of more skilled entrepreneurs (Neck and Greene, 2011). Entrepreneurship must be understood as a method incorporating both science and art, and students must possess other skills in addition to business management (Jack and Anderson, 1999). To encourage people to engage in entrepreneurial behavior, entrepreneurship education should emphasize not only the value of skills and key qualities for entrepreneurial action, but also the importance of cultivating pro-entrepreneurial attitudes (Joensuu et al, 2015). Individual attitudes toward entrepreneurship are linked to entrepreneurial motivation in the way that motivation is founded on values; in other words, the belief that entrepreneurship is advantageous or damaging, attractive or unfavorable (Locke, 2000). Fundamentally, inspiration entails both thought and effort, most of the study on the impact of effort (including persistence) and effort direction on job success has been based on the principle of motivation (Locke, 2000).

\section{Human Resources in Startup}

Human resource management (HRM) is the oversight of people in a work environment, either individually or collectively (Anca-Ioana, 2013). The value of HRM activities in the corporate climate includes employee support for building confidence in business leaders, which equates to high-quality organizational success (Cho et al., 2013). Human resource management has an effect on workforce productivity in small firms (Bhardwaj, 2013). A main motivation for creating the right human resource combination is to encourage small business owners to stop making careless decisions in response to consumer demands and pressures (Kotey \& Slade, 2005). Startup owners and workers should be provided with the necessary resources, expertise, capabilities, and experience to run their businesses efficiently (Brown, 2017).

\section{Business Motivational Factor}

Business motivation is the most critical element in creating an accomplishment experience in every organization, public or private (Chintallo \& Mahadeo, 2013). Organizations assume that their human resources and workforce are their most valuable assets, which can propel them to growth or, if not properly concentrated, contribute to decline (Manzoor, 2011). Self-Determination Theory (SDT) by (Ryan \& Deci, 2000) defines intrinsic and forms of extrinsic motivation, and also examines how these motivations affect behavioral responses in diverse aspects; social, cognitive performance and personality. SDT provides a comprehensive understanding of individual motivation and behavior. Individuals instinctively and deliberately orient themselves toward development and self-organization, 
according to the humanistic assumption. SDT also asserts natural growth tendency and basic psychological needs for autonomy, competence, and relatedness (L. Legault, 2020).

\section{Pivot Business}

In pivoting, six main factors influenced the firms under analysis, there are the following: the position of the founders, capital and finance, the feasibility of the business model, market dynamics, business financials, and emerging technologies (C. Comberg, A. German \& F. Seith, 2014). The most important people for the startup's business success and planning, with the finest history of the organization condition and knowledge from its current developments. Wisely, startups should question themselves on a daily basis if they should pivot, regardless of whether they have a solid or poor cash position. (C. Comberg, A. German \& F. Seith, 2014).

\section{Pivoting Business Affect Motivational Factors}

When startups discover that after so many attempts of the marketing plan, certain aspects in their idea or approach are faulty and that it is time to pivot, they use pivoting as a strategy for creating new objectives (Ries, 2011). Clarified by the fact that startup workers understand that working with startups entails a challenging environment of uncertainty regarding the business's long-term sustainability ( $F$. Meiners \& P. Costa, 2018). Pivoting creates significant changes in the company plan, which often has an impact on employees (McGinn, 2009). Employees may become overwhelmed and emotionally distracted when entrepreneurs pivot too often, and they may become demotivated by the founders' and the startup's initial concept (Kim 2016).

\section{Personality Traits}

Personality is a unique synthesis of an individual's mechanisms, personality behaviors, modes of thinking, desires and tendencies, talents, knowledge, and personality, as well as ways of thinking (Tanoğlu, 2008). According to the Big-Five Principle of Personality Traits, human characters may influence people's interpretations and responses to their surroundings (Santos, 2016). More impressively, personality is not strictly described at the individual level; furthermore, it may be upgraded into different layers of study for both improvement and decision-making processes (Church et al., 2014). One of the variables influencing corporate engagement is personality traits (McKay et al, 2013).

\section{Personality Traits Affect Motivation Factors}

Personality traits theory is inextricably linked to organizational motivation. In order to consider the identities of members of an organization, one must analyze their characteristics (Dinger FC, Dickhäuser O, Hilbig BE, Müller E, Steinmayr R, 2015). Personality was discovered to have a direct impact on organizational behavior in deciding degrees of tolerance, work environment consistency, and work ethics. The relationship between personality and motivation can be strengthened by putting individuals with compatible traits on the same teams where tolerance is likely to continue (Swider BW, Zimmerman RD, 2010). Another interpretation is that suiting motivation strategies from personality traits, by linking personalities towards motivation aspects, greatly increases the efficacy of organizational strategies (Greguras GJ, Diefendorff JM, 2010).

\section{Big Five Personality Traits}

The Big Five personality characteristics as determinants of an individual's entrepreneurial purpose (Zhao and Seibert, 2006). Recent meta-analyses have found that personality does play an important role in entrepreneurship, and prior observational studies in the study of individual personalities in relation to entrepreneurial purpose have confirmed it (Brandstätter, 2011). The antecedents of performance are the BFPT model. Conversely, with individuals' participation in practice, these characteristics may have an impact on performance (Amir et al, 2014). The implementation of the Big Five Personality Traits by several researchers on the implementation of business and employee concluded that, "Our findings 
indicate that cultural control \& big five personality traits affects organizational commitment positively, the major finding of this study was that the relationship between at least two of the Big Five personality traits (conscientiousness and agreeableness) to the organizational commitment." (Lennartsson \& Dan, 2020). "When workers of a company display good personality traits, group success increases, due to attracting the right workers with positive traits that will successfully cultivate team spirit, job togetherness, and ensure the achievement of the organization's objectives and goals." (Adeyemi \& Damilola, 2018).

\section{Motivation Factors Affect Motivation}

Entrepreneurs are motivated by four distinct factors; extrinsic incentives, independence/autonomy, intrinsic rewards, and family stability (Robichaud, McGraw and Roger, 2001). Motivation factors are associated with the demands of an entrepreneurial position, which tends to draw highly achievementmotivated individuals due to the capacity for greater achievement fulfillment in an entrepreneurial environment, a framework that offers the challenge, autonomy, and flexibility for achievement realization (Stewart and Roth, 2007). Motivation factors used by authors refer to Self Determination Theory (SDT) by (R.M. Ryan and E.L. Deci, 2000). Self Determination Theory concentrates on naturally relational supports and understands the various types of motivational stimulation that influence human behavior. In SDT human motivation is considered in a differentiated way, individual motivation factors are not able to be assessed with only more or less motivated tendency, but the motivated individuals are able to analyze deeper related to their varied types of intrinsic motivation factors \& extrinsic motivation factors (Keifer, G \& Effenberger, F, 1967).

\section{Conceptual Framework}

This research has problem identification and root cause based on the internal current condition in Chixar poultry business. Focused problem which has been observed by the author is the personality traits and supporting factors to influence business motivation and engagement in Chixar business members. In this problem identification stage, authors identify that personality traits and motivation problems in internal business are issues that need not be addressed, the problem of employee motivation is often being ignored in the scope of small to large scale businesses that the author found through preliminary studies. Chixar's business members did not seem very enthusiastic in pursuing the sales target which was quite high, this was influenced by the motivation between members who tended to be unstable. Motivation to do business that is not stable is very influential on the orientation and business goals that have the potential not to achieve the expected sales performance. Seeing the phenomenon of sales target reduction is influenced by internal factors such as a lack of confidence and motivation in achieving business targets. The things that indicate low motivation to achieve sales targets are influenced by Chixar business members who have just started a highly targeted business on sales aspects, lack of confidence due to high sales targets and low potential for sales channels at the time, especially the unstable motivation at Chixar business members. influenced by the lack of strengthening motivation among others, the lack of bonding activities and the absence of direct interaction between members.

Figure 1: Conceptual Framework

\begin{tabular}{|c|c|c|}
\hline $\begin{array}{c}\text { Personality Traits } \\
\text { (Big Five Personality } \\
\text { Traits) }\end{array}$ & $\begin{array}{c}\text { Motivation Factors } \\
\text { (Self Determination Theory) } \\
\text { Intrinsic Factor } \\
\text { (Autonomy, Competences \& } \\
\text { Relatedness) } \\
\text { Extrinsic Factor } \\
\text { (External Regulation, Integrated } \\
\text { Regulation, Identified Regulation \& } \\
\text { Introjected Regulation) }\end{array}$ & Motivation \\
\hline
\end{tabular}




\section{Methodology}

This research will conduct a qualitative approach by processing information and data analysis using coding and big five personality traits testing to reach the qualified research result. Qualitative methods can be used to improve the quality of information-based qualitative evaluations by helping generate evaluation hypotheses; strengthening the design of survey questionnaires and expanding or clarifying qualitative evaluation findings (Megel and Mary Erickson, 1994). Main purpose qualitative research approach used for observing deeply of types of personality traits and common other supporting motivation factors in Chixar business members. Researcher conducting in-depth interviews, focus group discussion, pilot test and big five personality traits testing and self-determination theory testing method. Authors concluded to proposed implemented performance management system for small business and startup as a recommendation for internal Chixar probiotic poultry business.

Figure 2: Conceptual Framework

\begin{tabular}{|c|c|}
\hline $\begin{array}{l}\text { Problem } \\
\text { Identification }\end{array}$ & $\begin{array}{c}\text { Personality Traits \& Supporting Factors to Influence } \\
\text { Business Motivation }\end{array}$ \\
\hline Literature Review & $\begin{array}{c}\text { Entrepreneurship Motivation } \\
\text { Human Resources in Startup } \\
\text { Business Motivational Factor } \\
\text { Pivot Business } \\
\text { Pivoting Business Affect Motivational Factors } \\
\text { Personality Traits } \\
\text { Personality Traits Affect Motivation Factors } \\
\text { Big Five Personality Traits } \\
\text { Motivation Factors Affect Motivation }\end{array}$ \\
\hline $\begin{array}{c}\text { Data } \\
\text { Collection }\end{array}$ & $\begin{array}{c}\text { In Depth Interview } \\
\text { Focus Group Discussion } \\
\text { Pilot Test } \\
\text { Big Five Personality Traits } \\
\text { Self Determination Theory }\end{array}$ \\
\hline $\begin{array}{c}\text { Data } \\
\text { Analysis }\end{array}$ & $\begin{array}{c}\text { Coding } \\
\text { Qualitative Descriptive Analytics }\end{array}$ \\
\hline $\begin{array}{c}\text { Conclusion \& } \\
\text { Recommendation }\end{array}$ & $\begin{array}{l}\text { Proposed Performance Management } \\
\text { System }\end{array}$ \\
\hline
\end{tabular}

\section{Analysis \& Result}

\section{Big Five Personality Traits}

\section{Extraversion Personality Traits}

Based on the assessment of the big five personality traits, the authors found several results and findings related to the findings of personality extraversion. Looking at some of the sub-variables tested by the assessment, it can be seen that Nadia Ambar Shofiya (member 1) has the highest score in the extraversion personality category through the Big Five Personality Traits assessment. The way they get along and interact, it can be seen that Nadia Ambar Shofiya (member 1) is used to starting a topic of conversation first to melt the atmosphere of the conversation with the other person, whether it is someone she knows or new get acquainted and they feel happy when they become the center of attention in certain situations and conditions. This extraversion personality is known as a person who is famous for being easy to get along with, easy to adapt to various environments and creates high selfconfidence for individuals to interact with various types of groups, individuals and various conditions. 
Table 1: Big Five Personality Traits Result
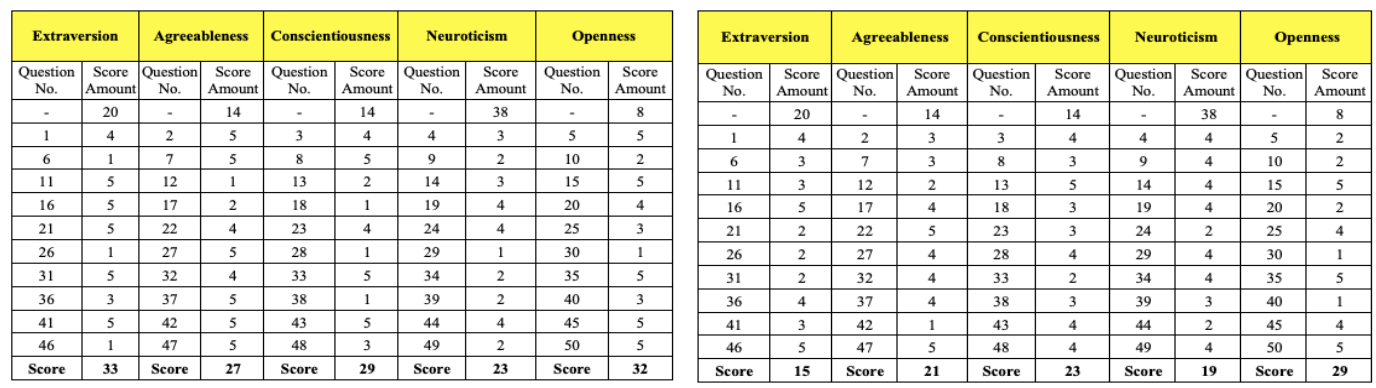

\section{Openness Personality Traits}

The results of the Big Five Personality Traits assessment were also given to Fadhilah Rania (member 2). Which showed that Fadhilah Rania (member 2) had a very strong tendency and led to openness personality traits such as having vivid imaginations, feeling happy when communicating excellent ideas, being responsive in understanding a problem, often reflects on various things at a certain time and is always interested and full of interesting ideas. has a tendency to follow and adapt more to the working culture that has been created which is balanced with her abilities and capabilities, thereby increasing and maintaining her motivation. In terms of self-values, Fadhilah Rania (member 2) has a strong belief in the values or principles of life that have good connotations such as religious teachings and social norms. In the aspect of open minded working culture which is starting to be applied in business conditions or work environments which means individuals are accustomed to having a willingness to understand, listen to opinions, ideas, suggestions and criticisms from others, Fadhilah Rania (member 2) responds with the concept of an open minded working culture. This is considered good and implementable, but regulations are needed to avoid behavior or behavior that violates the concept of an open minded working culture itself, for all of them there must be clear boundaries and stipulations of rules.

\section{Self Determination Theory}

\section{Intrinsic Motivation}

\section{Relatedness}

Table 2: Self Determination Theory (Intrinsic) Result

\begin{tabular}{|c|c|c|c|c|c|}
\hline \multicolumn{2}{|c|}{ Autonomy } & \multicolumn{2}{c|}{ Competences } & \multicolumn{2}{c|}{ Relatedness } \\
\hline $\begin{array}{c}\text { Question } \\
\text { No. }\end{array}$ & $\begin{array}{c}\text { Score } \\
\text { Amount }\end{array}$ & $\begin{array}{c}\text { Question } \\
\text { No. }\end{array}$ & $\begin{array}{c}\text { Score } \\
\text { Amount }\end{array}$ & $\begin{array}{c}\text { Question } \\
\text { No. }\end{array}$ & $\begin{array}{c}\text { Score } \\
\text { Amount }\end{array}$ \\
\hline 1 & 4 & 3 & 2 & 2 & 5 \\
\hline 4 & 1 & 5 & 5 & 6 & 5 \\
\hline 8 & 5 & 10 & 5 & 7 & 1 \\
\hline 11 & 5 & 13 & 4 & 9 & 5 \\
\hline 14 & 2 & 15 & 2 & 12 & 5 \\
\hline 17 & 5 & 19 & 2 & 16 & 2 \\
\hline 20 & 1 & & & 18 & 2 \\
\hline & & & & 21 & 5 \\
\hline Score & $\mathbf{2 3}$ & Score & $\mathbf{2 0}$ & Score & $\mathbf{3 0}$ \\
\hline
\end{tabular}

\begin{tabular}{c|c|c|c|c|c|}
\hline \multicolumn{2}{c|}{ Autonomy } & \multicolumn{2}{c|}{ Competences } & \multicolumn{2}{c|}{ Relatedness } \\
\hline $\begin{array}{c}\text { Question } \\
\text { No. }\end{array}$ & $\begin{array}{c}\text { Score } \\
\text { Amount }\end{array}$ & $\begin{array}{c}\text { Question } \\
\text { No. }\end{array}$ & $\begin{array}{c}\text { Score } \\
\text { Amount }\end{array}$ & $\begin{array}{c}\text { Question } \\
\text { No. }\end{array}$ & $\begin{array}{c}\text { Score } \\
\text { Amount }\end{array}$ \\
\hline 1 & 4 & 3 & 4 & 2 & 3 \\
\hline 4 & 5 & 5 & 3 & 6 & 5 \\
\hline 8 & 2 & 10 & 4 & 7 & 2 \\
\hline 11 & 4 & 13 & 3 & 9 & 4 \\
\hline 14 & 3 & 15 & 5 & 12 & 2 \\
\hline 17 & 3 & 19 & 5 & 16 & 5 \\
\hline 20 & 4 & & & 18 & 3 \\
\hline & & & & 21 & 5 \\
\hline Score & $\mathbf{2 5}$ & Score & $\mathbf{2 4}$ & Score & $\mathbf{2 9}$ \\
\hline
\end{tabular}

In the intrinsic motivation factor, it shows that both Chixar business members have the same intrinsic motivation factor, it is Relatedness. Relatedness is one type of intrinsic motivation factor that has been agreed upon by Chixar business members, the agreement the author concludes that Relatedness is an intrinsic motivation factor that is implemented especially in internal small businesses, it is seen that both Chixar member businesses have a strong tendency that building and developing businesses are based on by the factor of similarity in the aspect of internal equality to jointly carry out their functions 
in building a business, both business members of Chixar agreed that the attitude of respect and interrelation between business members is a fundamental aspect, where the harmony of good relations becomes a strong aspect in the relationship between members and motivates in business. The flow of communication and freedom of expression/opinion are things that also support business motivation because the obstruction of the flow of communication will greatly complicate the internal interaction process. For both of them, managing a business is a job that certainly discusses various aspects thoroughly and in detail on a regular basis, therefore the foundation of commitment, a supportive business environment and openness between members will greatly affect the transparency of the performance process that increases business motivation

\section{Extrinsic Motivation}

\section{Integrated Regulation}

In the extrinsic motivation, it shows that the two Chixar business members have different extrinsic motivation factors. tendency towards Integrated Regulation. However, based on the results of the agreement, it shows that both Chixar business members agree that Integrated Regulation is an extrinsic motivation which is an extrinsic motivation factor that is agreed and implemented in internal business, especially in small businesses, it can be seen that in discussions and decisions between members it shows that Integrated Regulations have a tendency that business motivation formed is influenced by the commitment and attachment factors shown through the real contribution of business members, as well as the synergy on the basis of the business vision and mission that is generated between members is able to spur business motivation because of the harmony of understanding between members. Chixar business members agree that conflicts and disagreements are natural aspects and actually strengthen motivation and commitment between businesses, because problems should be used as internal evaluations, therefore these conditions have the potential to increase commitment, trust and strengthen internal business.

Table 3: Self Determination Theory (Extrinsic) Result

\begin{tabular}{|c|c|c|c|c|c|c|c|}
\hline \multicolumn{2}{|c|}{ Integrated Regulation } & \multicolumn{2}{l|}{ Identified Regulation } & \multicolumn{2}{l|}{ Introjected Regulation } & \multicolumn{2}{l|}{ External Regulation } \\
\hline $\begin{array}{c}\text { Question } \\
\text { No. }\end{array}$ & $\begin{array}{c}\text { Score } \\
\text { Amount }\end{array}$ & $\begin{array}{c}\text { Question } \\
\text { No. }\end{array}$ & $\begin{array}{c}\text { Score } \\
\text { Amount }\end{array}$ & $\begin{array}{c}\text { Question } \\
\text { No. }\end{array}$ & $\begin{array}{c}\text { Score } \\
\text { Amount }\end{array}$ & $\begin{array}{c}\text { Question } \\
\text { No. }\end{array}$ & $\begin{array}{c}\text { Score } \\
\text { Amount }\end{array}$ \\
\hline 1 & 5 & 4 & 1 & 7 & 5 & 10 & 2 \\
\hline 2 & 5 & 5 & 1 & 8 & 5 & 11 & 2 \\
\hline 3 & 2 & 6 & 4 & 9 & 5 & 12 & 5 \\
\hline Score & $\mathbf{1 2}$ & Score & $\mathbf{6}$ & Score & $\mathbf{1 5}$ & Score & $\mathbf{9}$ \\
\hline
\end{tabular}

\begin{tabular}{|c|c|c|c|c|c|c|c|}
\hline \multicolumn{2}{|l|}{ Integrated Regulation } & \multicolumn{2}{l|}{ Identified Regulation } & \multicolumn{2}{l|}{ Introjected Regulation } & \multicolumn{2}{l|}{ External Regulation } \\
\hline Question No. & $\begin{array}{l}\text { Score } \\
\text { Amount }\end{array}$ & Question No. & $\begin{array}{l}\text { Score } \\
\text { Amount }\end{array}$ & Question No. & $\begin{array}{l}\text { Score } \\
\text { Amount }\end{array}$ & $\begin{array}{l}\text { Question } \\
\text { No. }\end{array}$ & $\begin{array}{l}\text { Score } \\
\text { Amount }\end{array}$ \\
\hline 1 & 5 & 4 & 3 & 7 & 5 & 10 & 3 \\
\hline 2 & 5 & 5 & 4 & 8 & 5 & 11 & 4 \\
\hline 3 & 4 & 6 & 5 & 9 & 3 & 12 & 5 \\
\hline Score & $\mathbf{1 4}$ & Score & $\mathbf{1 2}$ & Score & $\mathbf{1 3}$ & Score & $\mathbf{1 2}$ \\
\hline
\end{tabular}

\section{Proposed Performance Management System}

Regarding internal human resources problems faced by Chixar in order to increase employee motivation in internal business, the author proposes an implementable performance management system to be applied in small businesses \& startups. The author focuses on fundamental aspects that can have a significant impact on motivation and business performance, with the Performance Management framework: Seven Behaviors of Effective Coaches by Herman Aguinis. The framework includes 7 steps which have significant implications between a series of steps which include (Establish Development Objectives, Communicate Effectively, Motivate Employee, Document Performance, Feedback, Diagnose Performance Problems and Develop Employees).

\section{Conclusion}

Based on the overall results, it shows that there are two different personality traits between the two Chixar business members, Nadia Ambar Shofiya (member 1) is more likely to have Extraversion personality traits which tend to be energetic individuals, enthusiastic people, very socialable, comfort on socializing and interaction also easily for adaptation. Based on the Big Five Personality Traits 
assessment, it is shown that Fadhilah Rania (member 2) has a tendency towards Openness personality traits which has a tendency as an individual who likes to communicate ideas, is responsive in understanding problems and is always full and interested in creative and innovative ideas. The author concludes that individuals who have Openness personality traits are personalities who are implementable in Chixar's internal business, which is focused as a small and growing poultry business. Personality which includes Openness personality factors such as having a strong tendency to learn a new field that is able to support business performance, trying to implement innovation in business ideas and implementation, having high curiosity and being able to express ideas, opinions or proposals that are building business performance and responsible for the priorities and commitments that have been planned.

The results of the assessment method show that the intrinsic motivation of the two Chixar business members is relatedness as intrinsic motivation that affects motivation in doing business, this is shown by the tendency to feel happy and comfortable to interact intensively with various people, mutual respect seeks to be formed by each business member, influenced by close relationships, transparency among others, strong commitment, mutual understanding and trust and other intrinsic factors related to relatedness such as sub variables (Respect, Inclusive Environment, Acceptance by Others and Secure \& Support). In terms of extrinsic motivation factors, based on the results of an assessment related to Self Determination Theory (extrinsic motivation) it shows that there are two extrinsic motivation factors that have a strong tendency towards the two business members at Chixar, namely Integrated Regulations and Introjected Regulations. So that the author re-validates the statement and subvariables at the in-depth interview stage on the Integrated Regulation which includes sub-variables (Harmonious, Commitment, Quality of Relationship and Congruence) which are related to aspects of establishing a harmonious internal business environment, resolving internal conflicts, forming commitments. business, togetherness in doing business, commitment and responsibility, adaptive environmental adjustments and compatibility factors between members.

\section{References}

Adeyemi, M., \& Damilola, W. (2018). Effects of Big Five Personality Traits on Group Performance in AL-HIKMAH 1.

Amir, F., Naz, F., Qasim Hafeez, S., Ashfaq, A., \& Hameed Dogar, Y. (2014). Measureing the Effect of Five Factor Model of Personality on Team Performance with Moderating Role of employee engagement. Journal of Psychology and Behavioral Science, 2(2), 221-255. www.szabistisb.edu.pk

Anca Loana, 2009. (2013). No 主観的健康感を中心とした在宅高齢者における 健康関連指標に 関する共分散構造分析Title. Acta Universitatis Agriculturae et Silviculturae Mendelianae Brunensis, 53(9), 1689-1699.

http://publications.lib.chalmers.se/records/fulltext/245180/245180.pdf\%0Ahttps://hdl.handle.net/ 20.500.12380/245180\%0Ahttp://dx.doi.org/10.1016/j.jsames.2011.03.003\%0Ahttps://doi.org/10. 1016/j.gr.2017.08.001\%0Ahttp://dx.doi.org/10.1016/j.precamres.2014.12

Bhardwaj. (2013). Managerial Competencies and their Influence on Managerial Performance: A MANAGERIAL COMPETENCIES AND THEIR INFLUENCE ON MANAGERIAL PERFORMANCE : A LITERATURE REVIEW. January.

Brandstätter, H. (2011). Personality aspects of entrepreneurship: A look at five meta-analyses. Personality and Individual Differences, 51(3), 222-230. https://doi.org/10.1016/j.paid.2010.07.007

Chintalloo, S., \& Mahadeo, J. D. (2013). Effect of Motivation on Employees ' Work Performance at Ireland Blyth Limited. Proceedings of 8th Annual London Business Research Conference Imperial College, London, UK, 8 - 9 July, 2013, 8, 1-16.

Church, A. T. (2016). Personality traits across cultures. Current Opinion in Psychology, 8, 22-30. https://doi.org/10.1016/j.copsyc.2015.09.014

Comberg, C., German, A., Seith, F., \& Velamuri, V. (2014). Pivots in Startups : Factors Influencing Business Model Innovation in Startups. ISPIM Conference Proceedings. The International Society for Professional Innovation Management (ISPIM), June, 1-19. 
Dinger, F. C., Dickhäuser, O., Hilbig, B. E., Müller, E., Steinmayr, R., \& Wirthwein, L. (2015). From basic personality to motivation: Relating the HEXACO factors to achievement goals. Learning and Individual Differences, 40, 1-8. https://doi.org/10.1016/j.lindif.2015.03.023

Greguras, G. J., \& Diefendorff, J. M. (2010). Why does proactive personality predict employee life satisfaction and work behaviors? A field investigation of the mediating role of the selfconcordance model. Personnel Psychology, 63(3), 539-560. https://doi.org/10.1111/j.17446570.2010.01180.x

Jack, S. L., \& Anderson, A. R. (2002). The effects of embeddedness on the entrepreneurial process. Journal of Business Venturing, 17(5), 467-487. https://doi.org/10.1016/S0883-9026(01)00076-3

Keifer, G., \& Effenberger, F. (1967). Self Determination Theory Book (Ryan \& Deci). In Angewandte Chemie International Edition (Vol. 6, Issue 11).

Kim, S., Tam, L., Kim, J. N., \& Rhee, Y. (2017). Determinants of employee turnover intention: Understanding the roles of organizational justice, supervisory justice, authoritarian organizational culture and organization-employee relationship quality. Corporate Communications, 22(3), 308328. https://doi.org/10.1108/CCIJ-11-2016-0074

Kotey, B., \& Slade, P. (2005). Formal human resource management practices in small growing firms. Journal of Small Business Management, 43(1), 16-40. https://doi.org/10.1111/j.1540627X.2004.00123.x

Legault, L. (2020). Encyclopedia of Personality and Individual Differences. Encyclopedia of Personality and Individual Differences, 1-9. https://doi.org/10.1007/978-3-319-28099-8

Lennartsson, D. (2020). The relationship between personality traits, management control systems , and organizational commitment - a multifirm study Emil Sirén Gualinga.

Locke, E. A. (2000). Motivation, cognition, and action: An analysis of studies of task goals and knowledge. Applied Psychology, 49(3), 408-429. https://doi.org/10.1111/1464-0597.00023

Manzoor, Q.-A. (2011). Impact of Employees Motivation on Organizational Effectiveness. Business Management and Strategy, 3(1), 1-12. https://doi.org/10.5296/bms.v3i1.904

McGinn, D. (2012). Too many pivots, too little passion. Harvard Business Review, 90(9), 1-3.

Meiners, F., \& Costa, P. C. (2018). A dark side of pivoting? - The effect on employee motivation and commitment Dissertation written under the supervision of.

Meredith Martha Burkle, S. (2008). Education + Training Article information: learning perspective. Education + Training, 50(3), 199-215.

Neck, H. M., \& Greene, P. G. (2011). Entrepreneurship Education: Known Worlds and New Frontiers. Journal of Small Business Management, 49(1), 55-70. https://doi.org/10.1111/j.1540627X.2010.00314.X

Reuben L . Brown. (2017). SMALL BUSINESS OWNERS VIEWS AND PERCEPTIONS OF HUMAN RESOURCE MANAGEMENT PRACTICES: A Q METHODOLOGY STUDY by Reuben L . Brown Copyright 2017 A Dissertation Presented in Partial Fulfillment of the Requirements for the Degree Doctor of Business Administrat.

Ries, E. (2011). The Lean Startup: How Today's Entrepreneurs Use Continuous Innovation to Create Radically Successful Businesses Eric Ries. New York: Crown Business, 2011. 320 pages. US\$26.00. In Journal of Product Innovation Management (Vol. 29, Issue 3). https://doi.org/10.1111/j.1540-5885.2012.00920_2.x

Ryan, R. M., \& Deci, E. L. (2000). Intrinsic and Extrinsic Motivations: Classic Definitions and New Directions. Contemporary Educational Psychology, 25(1), 54-67. https://doi.org/10.1006/ceps.1999.1020

Santos, A., Mustafa, M., \& Chern, G. T. (2016). The Big Five personality traits and burnout among Malaysian HR professionals. Asia-Pacific Journal of Business Administration, 8(1), 2-20. https://doi.org/10.1108/APJBA-09-2014-0106

Stewart, W. H., \& Roth, P. L. (2015). 2007-A meta-analysis of achievement motivation differences between entrepreneurs and managers - Stewart Jr. e Roth.pdf. Journal of Small Business Management, 45(4), 401-421.

Swider, B. W., \& Zimmerman, R. D. (2010). Born to burnout: A meta-analytic path model of personality, job burnout, and work outcomes. Journal of Vocational Behavior, 76(3), 487-506. https://doi.org/10.1016/j.jvb.2010.01.003

Yves Robichaud, McGraw, R. (2001). Toward the development of a Measuring Instrument for Entrepreneurial Motivation. 
Malaysian Journal of Social Sciences and Humanities (MJSSH), Volume 6, Issue 8, (page 532 - 541), 2021

DOI: https://doi.org/10.47405/mjssh.v6i8.946

Zhao, H., \& Seibert, S. E. (2006). The big five personality dimensions and entrepreneurial status: A meta-analytical review. Journal of Applied Psychology, 91(2), 259-271. https://doi.org/10.1037/0021-9010.91.2.259 